\title{
EVALUATION OF THE RELATIONSHIP BETWEEN MORPHOLOGICAL CHARACTERISTICS AND PULLOUT RESISTANCE OF LIVE CUTTINGS OF Phyllanthus sellowianus (Klotzsch) Müll.Arg.
}

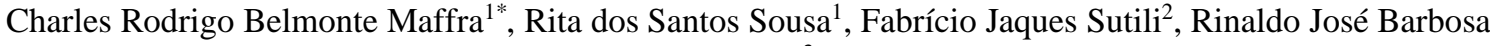 \\ Pinheiro ${ }^{3}$
${ }^{1 *}$ Universidade Federal de Santa Maria, Programa de Pós-graduação em Engenharia Florestal, Laboratório de Engenharia Natural, Santa Maria, Rio Grande do Sul, Brasil - charles.maffra@gmail.com, ritasousa.ufsm@gmail.com
${ }^{2}$ Universidade Federal de Santa Maria, Departamento de Engenharia Florestal, Laboratório de Engenharia Natural, Santa Maria, Rio Grande do Sul, Brasil - fjsutili@gmail.com
${ }^{3}$ Universidade Federal de Santa Maria, Centro de Tecnologia, Setor de Solos e Pavimentos, Santa Maria, Rio Grande do Sul, Brasil-rinaldo@ufsm.br

Received for publication: 25/02/2019 - Accepted for publication : 19/01/2021

\begin{abstract}
Resumo
Avaliação da relação entre as características morfológicas e a resistência ao arranquio de estacas de Phyllanthus sellowianus (Klotzsch) Müll.Arg. Este trabalho teve por objetivo avaliar a interdependência entre as características biométricas morfológicas e a capacidade de ancoragem de estacas de Phyllanthus sellowianus. Para isso foram realizados testes de arranquio vertical e de medições de diâmetro e comprimento de brotos e raízes de 144 estacas de 2,5 de diâmetro e $50 \mathrm{~cm}$ de comprimento, plantadas em espaçamento $1 \times 1 \mathrm{~m}$. As avaliações foram realizadas aos $60,133,186,252,320$ e 421 dias após o plantio e as diferenças entre os valores médios de crescimento e resistência ao arranquio vertical foram analisadas por meio do teste de Tukey e de equações de regressão linear. As plantas apresentaram os maiores valores médios de comprimento total de brotos $(875 \mathrm{~cm})$, comprimento total de raízes $(405 \mathrm{~cm})$ e resistência ao arranquio vertical $(1.5 \mathrm{kN})$ entre $252 \mathrm{e}$ 421 dias após o plantio. Nas estações mais favoráveis ao crescimento, as plantas aumentaram a sua resistência ao arranquio a uma taxa de $0,20 \mathrm{kN} / \mathrm{mês}$, sendo seguida por incrementos médios em comprimento total de brotos e raízes de 118,4 e $57,1 \mathrm{~cm} / \mathrm{mês}$, respectivamente. A resistência ao arranquio mostrou correlações positivas com todas as características morfológicas acima e abaixo do solo testadas, mas foi melhor explicada pela área transversal de brotos $\left(\mathrm{mm}^{2}\right)$, que apresentou $\mathrm{r}^{2}=0,55$. De modo geral, as variáveis biométricas de $P$. sellowianus propagada por estacas explicaram até metade das variações na resistência ao arranquio da espécie. Palavras-chave: arranquio vertical, resistência de raízes.
\end{abstract}

\begin{abstract}
This study aimed to evaluate the interdependence between the morphological characteristics and the pullout resistance of live cuttings of Phyllanthus sellowianus. Vertical pullout tests and shoot and root diameter and length measurements were performed in 144 live cuttings, with $2.5 \mathrm{~cm}$ in diameter and $50 \mathrm{~cm}$ in length, planted in $1 \times 1 \mathrm{~m}$ spacing. The evaluations were performed at $60,133,186,252,320$, and 421 days after planting, and the differences between mean growth and vertical pullout resistance values were analyzed using the Tukey test and linear regression equations. The plants showed the highest mean total shoot length $(875 \mathrm{~cm})$, total root length $(405 \mathrm{~cm})$, and vertical pullout resistance $(1.5 \mathrm{kN})$ values between 252 and 421 days after planting. The plants increased their pullout resistance at an average rate of $0.20 \mathrm{kN} /$ month in the most favorable growth periods, followed by average increments in the total shoot and root length of 118.4 and $57.1 \mathrm{~cm} / \mathrm{month}$, respectively. The pullout resistance showed positive correlations with all above- and below-ground morphological characteristics tested, but it was best explained by the cross-sectional area of shoots $\left(\mathrm{mm}^{2}\right)$ which showed $\mathrm{r}^{2}=0.55$. The biometric variables of $P$. sellowianus propagated from cuttings generally explained up to half of the variations in the species' pullout resistance.
\end{abstract}

Keywords: vertical pullout, root strength.

\section{INTRODUCTION}

Soil bioengineering solutions use live and inert materials for erosion control, slope, and streambank stabilization (SCHIECHTL; STERN 1996). Live materials are usually composed of plants, cuttings, and seeds, and inert materials by wood, rock, steel, synthetic polymers, and natural fibers (GRAY; SOTIR 1996). Inert materials have more homogeneous properties and more technical information to answer the engineer's needs during project phases in comparison to living materials (MAFFRA et al., 2017; MAFFRA; SUTILI, 2020). Live material properties are more difficult to measure and precisely quantify since genetic and environmental conditions control them. Hence, plant growth and development variations, especially those related to below-ground

FLORESTA, Curitiba, PR, v. 51, n. 2, p. 329-338, abril/jun 2021

Maffra, C. R. B. et.al.

ISSN eletrônico 1982-4688

DOI: $10.5380 /$ rf.v51 i2. 65159 
parameters (e.g., root strength), partially explain the technical information scarcity and absence of standard methods to evaluate plants' contributions to soil protection and reinforcement (SOUSA et al., 2020).

Several studies have been carried out in past years to evaluate plants' contribution to soil reinforcement (DOCKER; HUBBLE 2008; LOADES et al. 2010; SCHWARZ et al. 2010; MICKOVSKI et al. 2011). However, technical and practical information is still insufficient for the analytical needs of soil bioengineering. Furthermore, the main current methods to assess live materials, such as root tensile strength, shear strength, and pullout resistance (GENET et al. 2005; WU, 2013; WU et al. 2014; MAFFRA et al., 2017; MAFFRA et al., 2019) involve root system extraction, which can be expensive and time-consuming. Ideal methods should be simple, fast, economical, and non-destructive. These requirements have been successfully achieved in other areas (such as modeling plant growth and forest dynamics) by indirect methods such as using allometric relations to estimate above- and below-ground biomass of forest stands (JOHANSSON; HJELM 2012; FORTIER et al. 2015).

It is well known that root and shoot growth are interdependent and often exhibit positive correlations (LIU et al. 2014). This indication suggests that plants' above-ground characteristics, such as height, diameter, or the cross-sectional area of shoots, could be significantly correlated with root system anchorage capacity parameters (KARRENBERG et al. 2003; LIU et al., 2014), such as the cross-sectional area of roots (WU et al., 2014), tensile strength (GENET et al., 2005) or pullout resistance (LIU et al., 2014). If proven, this possible relationship could be used to quickly and economically predict the contribution of a plant's root system to soil reinforcement; this information is useful for designing soil bioengineering techniques for slope stabilization and to recover geotechnically unstable environments (SCHIECHTL; STERN 1996).

One of the most common bioengineering techniques for slope stabilization is the use of live cuttings, which involves inserting dormant cuttings into the ground (SCHIECHTL, 1973). This method provides immediate reinforcement to the soil, and tends to increase with root development. This technique has been used to evaluate plant anchorage and its effect on soil resistance, plant flooding tolerance, and plant contribution to slope stability (KARRENBERG et al. 2003; WU et al. 2014; LIN et al. 2010; LIU et al. 2014).

A series of reophyte species in southern Brazil, commonly known as sarandis, show great ease of vegetative propagation and great ability to stabilize soil (SUTILI et al., 2018). Among these sarandis species, Phyllanthus sellowianus (Klotzsch) Müll. Arg. is one of the most used in soil bioengineering techniques to stabilize riverbanks and reservoir margins (SOUSA et al. 2017). The species is native to South America and grows naturally on the riverbanks in southern Brazil, northeastern Argentina, and Uruguay (SUTILI et al., 2012). Furthermore, according to these authors, it is a branched bush of 2 to $3 \mathrm{~m}$ in height, with highly dense and flexible branches, high root density, exceptional resilience, and good growth in poor soils. These characteristics make the species an excellent option for restoring riparian environments and an initial suitable choice for studies which intend to verify the relationship between a plant's biometric characteristics and its anchoring capacity.

In view of the above, this study aimed to evaluate the relationship between above- and below-ground biometric characteristics and the anchoring capacity of live cuttings of Phyllanthus sellowianus using the coefficient of determination $\left(\mathrm{r}^{2}\right)$ generated from linear equations. In this work, we seek to generate information which will promote plant use as an engineering material in slope recovery and stabilization, especially in rivers and dam reservoirs.

\section{MATERIAL AND METHODS}

\section{Study site and experimental set up}

The experiment was carried out in São João do Polêsine, Rio Grande do Sul, Brazil (29 39'8.64" S; 53 $\left.31^{\prime} 40.52^{\prime \prime} \mathrm{W}\right)$. The experiment site is about $150 \mathrm{~m}$ above sea level and is characterized by a subtropical Cfa wet climate according to the Köppen classification (ALVARES et al., 2013), with an average annual precipitation of $1600 \mathrm{~mm}$ and an average annual temperature of $19.7^{\circ} \mathrm{C}$, respectively. The soil in the study area is of colluvial origin, characterized as up to $1.0 \mathrm{~m}$ of depth with sand, silt, and clay contents of 74.6, 17.8, and 7.6\%, respectively. The soil density is $1.43 \mathrm{~g} / \mathrm{cm}^{3}$, and the porosity is $0.45 \mathrm{~m}^{3} / \mathrm{m}^{3}$ (Table 1). Due to the predominance of the sand fraction, the soil shear strength is low at about $6.4 \mathrm{kPa}$, and the internal friction angle of $27.3^{\circ}$ (ASTM D3080:2011). The soil is acidic, and it has an average amount of potassium and low phosphorus, organic matter, and aluminum levels (Table 1).

The experiment area is $17 \mathrm{~m}$ long and $7 \mathrm{~m}$ wide $\left(119 \mathrm{~m}^{2}\right)$. The area was prepared to receive planting by weed mowing and ant control using a Fipronil-based formicide. Maintenance of the area was performed using the same procedures. Next, a total of 144 cuttings of Phyllanthus sellowianus of $50 \mathrm{~cm}$ in length and $2.5 \mathrm{~cm}$ in diameter were planted in pits of $40 \mathrm{~cm}$ of depth and $15 \mathrm{~cm}$ in diameter, according to a $1 \mathrm{x} 1 \mathrm{~m}$ spacing. Cuttings were inserted $40 \mathrm{~cm}$ into the soil in the planting procedure, leaving only $10 \mathrm{~cm}$ outside. The experiment was divided into six evaluation periods, each containing 24 cuttings (i.e. 24 repetitions evaluated per period). Temperature and

FLORESTA, Curitiba, PR, v. 51, n. 2, p. 329-338, abril/jun 2021 
precipitation data were collected monthly. Data on plant growth were collected at $61,133,186,252,320$, and 421 days after planting.

Table 1. Physical and chemical characteristics of the soil in the study area.

Tabela 1. Características físicas e químicas do solo da área de estudo.

\begin{tabular}{|c|c|c|c|c|c|c|c|c|c|c|c|}
\hline \multirow{3}{*}{$\begin{array}{l}\text { Depth } \\
(\mathrm{cm})\end{array}$} & \multicolumn{6}{|c|}{ Physical } & \multicolumn{5}{|c|}{ Chemical } \\
\hline & \multicolumn{3}{|c|}{$\begin{array}{c}\text { Granulometry } \\
(\%)\end{array}$} & \multirow{2}{*}{$\begin{array}{c}\text { Soil } \\
\text { density } \\
\left(\mathrm{g} / \mathrm{cm}^{3}\right)\end{array}$} & \multirow{2}{*}{$\begin{array}{l}\text { Particle } \\
\text { density } \\
\left(\mathrm{g} / \mathrm{cm}^{3}\right)\end{array}$} & \multirow{2}{*}{$\begin{array}{c}\text { Porosity } \\
\left(\mathrm{cm}^{3} / \mathrm{cm}^{3}\right)\end{array}$} & \multirow{2}{*}{$\begin{array}{c}\mathrm{P} \\
\left(\mathrm{mg} / \mathrm{dm}^{3}\right)\end{array}$} & \multirow{2}{*}{$\begin{array}{c}\mathrm{K} \\
\left(\mathrm{mg} / \mathrm{dm}^{3}\right)\end{array}$} & \multirow{2}{*}{$\begin{array}{c}\text { Organic } \\
\text { Matter } \\
\% \text { M.O. }\end{array}$} & \multirow{2}{*}{$\begin{array}{c}\mathrm{Al} \\
\left(\mathrm{cmolc} / \mathrm{dm}^{3}\right)\end{array}$} & \multirow[t]{2}{*}{$\mathrm{pH}$} \\
\hline & Sand & Silt & Clay & & & & & & & & \\
\hline $0-20$ & 78.0 & 14.0 & 8.0 & 1.36 & 2.60 & 0.47 & 32.3 & 136.0 & 1.0 & 0.6 & 4.8 \\
\hline $20-40$ & 79.0 & 15.0 & 6.0 & 1.38 & 2.60 & 0.47 & 33.4 & 84.0 & 0.5 & 0.6 & 5.0 \\
\hline $40-60$ & 75.0 & 18.0 & 7.0 & 1.47 & 2.60 & 0.43 & 17.1 & 60.0 & 0.5 & 1.0 & 5.0 \\
\hline $60-80$ & 73.0 & 20.0 & 7.0 & 1.48 & 2.60 & 0.43 & 11.8 & 60.0 & 0.4 & 1.2 & 4.9 \\
\hline $80-100$ & 68.0 & 22.0 & 10.0 & 1.47 & 2.60 & 0.43 & 5.3 & 64.0 & 0.4 & 0.6 & 5.0 \\
\hline Média & 74.6 & 17.8 & 7.6 & 1.43 & 2.60 & 0.45 & 19.98 & 80.8 & 0.56 & 0.8 & 4.9 \\
\hline
\end{tabular}

The live cuttings used were collected from several matrix plants on the banks of the Vacacaí river, in Santa Maria, RS. The straightest cuttings of approximately $2 \mathrm{~cm}$ in diameter were chosen and cut at a height of 30 $\mathrm{cm}$ from the matrix plants' base with pruning shears. This procedure was performed because the P. sellowianus cutting base is normally tortuous and could cause greater resistance in the pullout test.

The soil where the cuttings were planted did not receive any special preparation except opening pits to insert the cuttings and monthly control of weed growth by mowing. This approach was chosen because the species used in soil bioengineering should show good development in poor and acidic soils, demonstrating adaptation to the place where they will be inserted. Moreover, there is no information about recommending fertilization and soil correction for the P. sellowianus species.

\section{Vertical pullout tests}

A special tripod was designed and manufactured entirely in steel to implement the vertical pullout tests (Figure 1a). This tripod is portable and adjustable to irregular surfaces, and was prepared to support an electric winch with a continuous-torque and constant uplift rate. The winch steel rope was passed through a centralized sheave at the top of the tripod to maintain applied forces in a perpendicular position. A force transducer with maximal support of $10 \mathrm{kN}$ was attached to the winch steel rope's tip and connected to a carrier frequency amplifier which reads the signals and sends them to a laptop computer, which then instantly stores the data (Figure $1 \mathrm{~b}$ and 1c). These data provided the maximal vertical pullout force indicative of the plant's anchorage capacity.
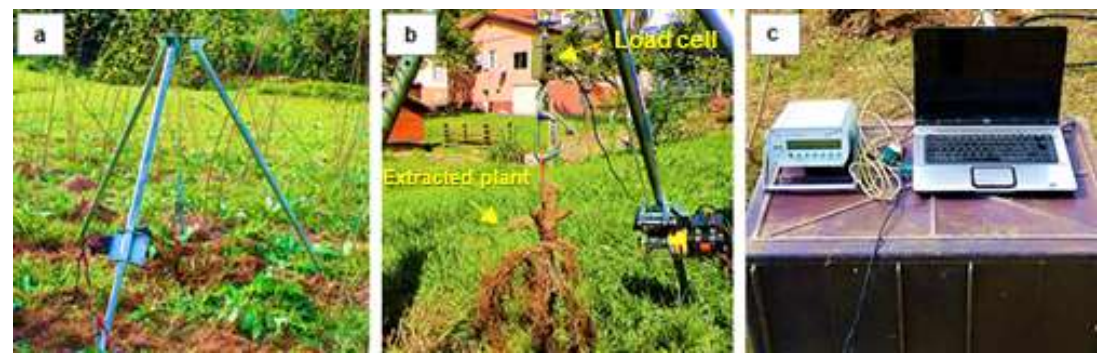

Figure 1. The general aspect of the equipment used in the vertical pullout tests. a) The tripod which supports an electric motor, steel cable, and load cell; b) Aspects of the load cell and one of the plants extracted from the soil; c) Aspects of the data acquisition system.

Figura 1. Aspectos gerais do equipamento usado nos testes de arranquio vertical. a) Tripé que dá suporte ao motor elétrico, cabo de aço e célula de carga; b) Aspectos da célula de carga e do sistema radicial de uma das plantas extraídas do solo; c) Aspectos do sistema de aquisição de dados.

All plant branches had to be previously removed using pruning shears to enable the electric winch to be attached to the plants. We always tried to leave some branches to allow the rope wrapped around the cutting base to be well fixed/secure to prevent it from sliding during the test.

Figure 2 shows the general aspects of the plant pullout test. The initial phase of the process (Figure 2, image 1) is characterized by activating the electric motor and the consequent vertical force application which must extract the plant. In this same step, the software is commanded to start automatically reading and recording the force $(\mathrm{kN})$ and time (duration) data. Then in phases 2 to 8 , the plant's root system is observed to be extracted from the soil at an approximate speed of $2 \mathrm{~cm} / \mathrm{s}$, and the resistance to scratching data is automatically recorded in the

FLORESTA, Curitiba, PR, v. 51, n. 2, p. 329-338, abri1/jun 2021.

Maffra, C. R. B. et.al.

ISSN eletrônico 1982-4688

DOI: $10.5380 /$ rf.v51 i2. 65159 
software installed on the laptop computer. Phase 9 is the end of the test in which the root system was extracted, the force reading drops to $0 \mathrm{~N}$, the engine is turned off, and the software stops the readings.

The vertical pullout tests were carried out between 1 and 4 days after an intense rainfall event to minimize soil moisture variations. The soil water content was monitored according to the degree of soil saturation $(\mathrm{S}=$ volume of water/volume of voids). Such an approach allowed the tests to be performed under similar soil moisture conditions, with a degree of saturation value of around $80 \%$ in each evaluation period.
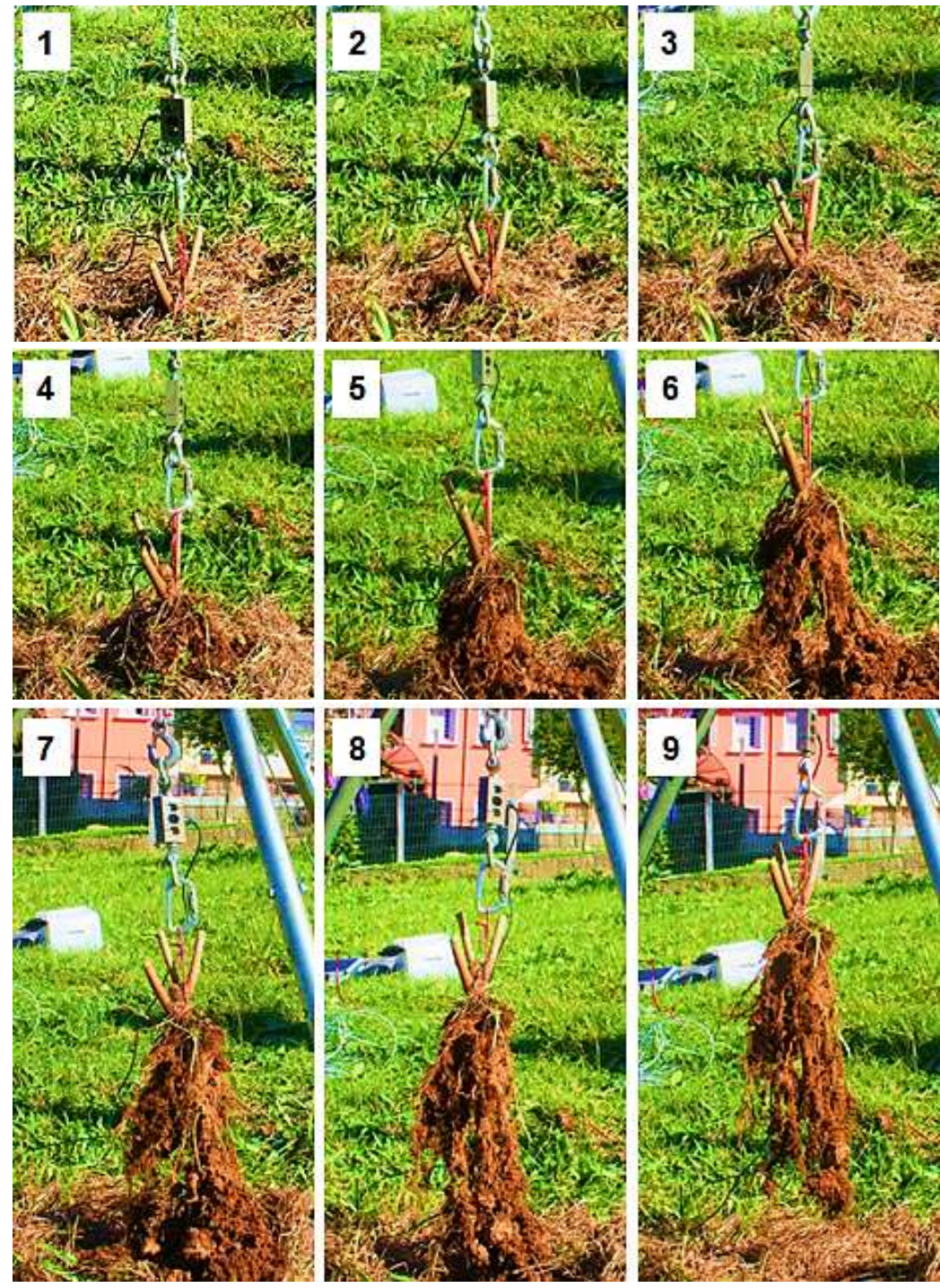

Figure 2. Pullout of a Phyllanthus sellowianus plant 252 days after planting. Image 1 represents the beginning of the test by activating the command which starts the electric motor; The test is in progress between images 2 and 8; Image 9 corresponds to the end of the test.

Figura 2. Arranquio de uma planta de Phyllanthus sellowianus 252 dias após o plantio. A imagem 1 representa o início do ensaio por acionamento do comando que liga o motor elétrico; Entre as imagens 2 e 8 , o ensaio encontra-se em andamento; A imagem 9 corresponde ao encerramento do ensaio.

\section{Plant biometric measurements}

The measurements of morphological parameters were carried out at two different times: 1) Before vertical pullout tests (on the same day of the test): live cutting diameter $(\mathrm{mm})$ and number, length $(\mathrm{cm})$ and diameter $(\mathrm{mm})$ of shoots; 2) After vertical pullout tests: number, length $(\mathrm{cm})$ and diameter $(\mathrm{mm})$ of the roots. These variables were measured using a caliper and a ruler, and were used to obtain the following above- and below-ground plant information:

FLORESTA, Curitiba, PR, v. 51, n. 2, p. 329-338, abril/jun 2021 


\section{Above-ground}

1) Cross-sectional area of shoots $\left(\mathrm{mm}^{2}\right)$, CSAS - This is the sum of the cross-sectional area of the shoots of a plant;

$$
C S A S=\left(\frac{d s_{1}{ }^{2} \cdot \pi}{4}\right)+\left(\frac{d s_{2}{ }^{2} \cdot \pi}{4}\right)+\ldots+\left(\frac{d s_{n}{ }^{2} \cdot \pi}{4}\right)
$$

2) Diameter of cuttings, DC $(\mathrm{cm})$ - This is the diameter of a plant cutting;

3) Total length of shoots, TLS (cm) - This is the length sum of the shoots of a plant;

$$
T L S=l s_{1}+l s_{2}+\ldots+l s_{n}
$$

4) Total diameter of shoots, TDS (mm) - This is the diameter sum of the shoots of a plant;

$$
T D S=d s_{1}+d s_{2}+\ldots+d s_{n}
$$

5) Mean diameter of shoots, MDS (mm) - This is the mean diameter of the shoots of a plant;

$$
M D S=\frac{T D S}{N S}
$$

6) Mean cross-sectional area of shoots, MCSAS $\left(\mathrm{mm}^{2}\right)$ - This is the mean cross-sectional area of the shoots of a plant;

$$
M C S A S=\frac{C S A S}{N S}
$$

7) Mean length of shoots (cm), MLS - This is the average length of the shoots of a plant;

$$
M L S=\frac{T L S}{N S}
$$

In which: $d s$, diameter of shoots; $l s$, length of shoots; $N s$, number of shoots.

\section{Below-ground}

1) Total diameter of roots, TDR $(\mathrm{mm})$ - This is the diameter sum of the roots of a plant. This variable is measured at the base of the roots, where the root is attached to the cutting;

$$
T D R=d r_{1}+d r_{2}+\ldots+d r_{n}
$$

2) Total length of roots, TLR $(\mathrm{cm})$ - This is the length sum of the roots of a plant;

$$
T L R=l r_{1}+l r_{2}+\ldots+l r_{n}
$$

3) Total number of roots - This is the total number of roots of a plant;

4) Mean diameter of roots, MDR ( $\mathrm{mm})$ - This is the mean diameter of the roots of a plant;

$$
M D R=\frac{T D R}{N r}
$$

5) Cross-sectional area of roots at rupture point, $\operatorname{CSAR}\left(\mathrm{mm}^{2}\right)$ - This is calculated using the diameter of the root at the point where it broke after the pullout test;

$$
\operatorname{CSAR}=\left(\frac{d r_{1}^{2} \cdot \pi}{4}\right)+\left(\frac{d r_{2}^{2} \cdot \pi}{4}\right)+\ldots+\left(\frac{d r_{n}^{2} \cdot \pi}{4}\right)
$$

In which: $d r$, diameter of roots; $l r$, length of roots; $N r$, number of roots.

All the variables mentioned above were used to obtain linear relations with the maximal vertical pullout force. The morphological variable which best described the root system resistance variations was selected from the established linear relationships using the coefficient of determination $\left(\mathrm{r}^{2}\right)$ as a classification parameter.

\section{Data analyses}

Variations in maximal vertical pullout resistance and shoot and root development were evaluated using a one-way analysis of variance (ANOVA). Coefficients of determination $\left(\mathrm{r}^{2}\right)$ were used to investigate the relations between the plants' above- and below-ground traits and cutting anchorage capacity. All analyses were performed using the MS Excel and SAS 9.2 software programs.

FLORESTA, Curitiba, PR, v. 51, n. 2, p. 329-338, abril/jun 2021 


\section{RESULTS}

\section{Growth and pullout resistance}

The live cuttings began to sprout three weeks after planting. The total survival rate was $90 \%$ with the evaluations performed with 130 plants.

As can be seen in Figure 3, the cuttings' growth and vertical pullout resistance showed very similar tendencies. Growth and vertical pullout resistance values increase together until the end of autumn (252-days old), decrease with dormancy period in winter (320-days old), and return to growth in the spring ( 421 days old). These similar variations point to a strong correlation between shoot characteristics, root system characteristics, and vertical pullout resistance. It also suggests that the non-linear behavior of the cuttings' growth, which increases and decreases according to the season, could be best represented with data arrangement into classes.

The Tukey test confirmed the differences between average plant growth values and vertical pullout resistance (Figure 3). This analysis shows that the highest average values of total shoot length $(875 \mathrm{~cm})$, total root length $(405 \mathrm{~cm})$, and vertical pullout resistance $(1.5 \mathrm{kN})$ occurs between later autumn and mid-spring (i.e. between 252 and 421-days old). The only exception during this period occurs in winter at 320-days old, where the values decreased and were statistically different. This occurs with the total shoot length and pullout resistance, but not with total root length. Total root length showed no significant difference between 252, 320, or 421-days old.

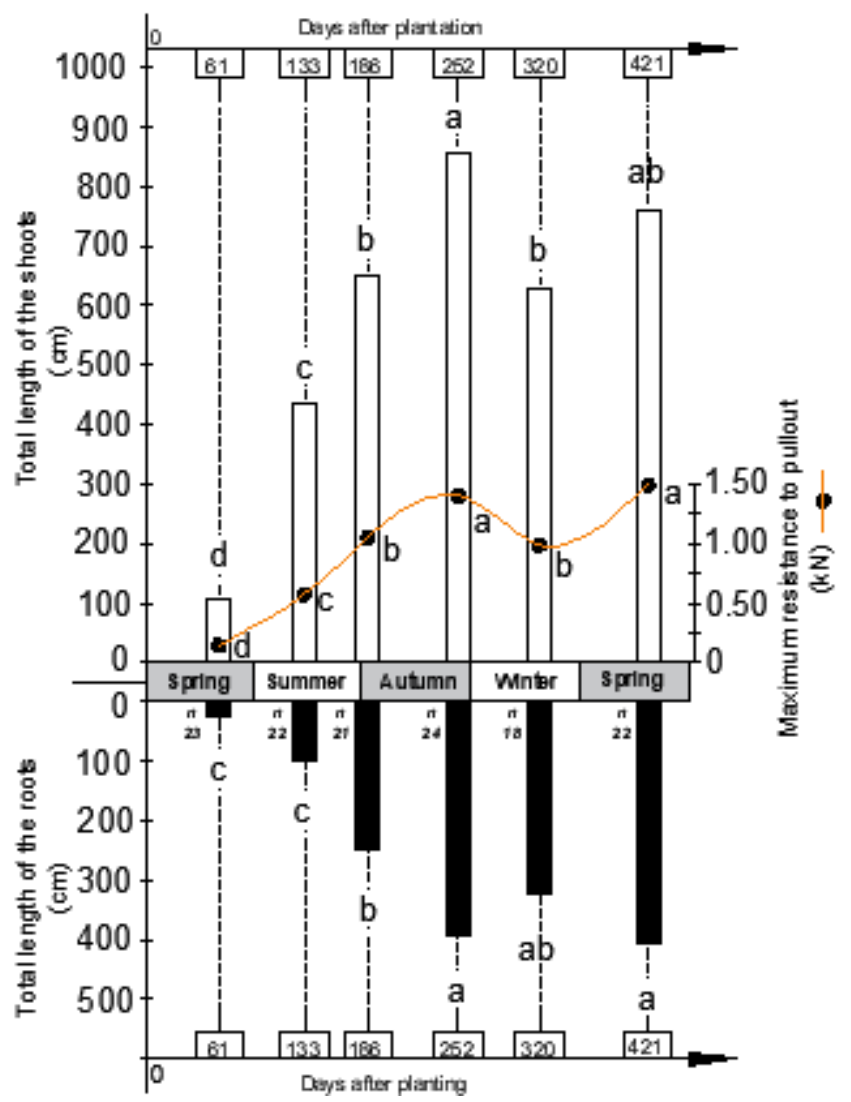

Values followed by the same letter are not statistically different according to the Tukey test $(\mathrm{P}<0.05)$; $\mathrm{n}$ is the number of live cuttings tested.

Figure 3. Relationship between cuttings' vertical pullout resistance and the total shoot and root length of Phyllanthus sellowianus.

Figura 3. Relação entre a resistência ao arranquio vertical de estacas e o comprimento total dos brotos e raízes de Phyllanthus sellowianus.

\section{Relationship between morphological characteristics and root system resistance}

Table 2 shows the coefficient of determination $\left(\mathrm{r}^{2}\right)$ for the relationship between morphological parameters (shoots and roots) and vertical pullout resistance. 
Table 2 - Coefficients of determination $\left(\mathrm{r}^{2}\right)$ of linear regression equations obtained from observed values. Tabela 2 - Coeficientes de determinação $\left(\mathrm{r}^{2}\right)$ de equações de regressão lineares obtidas de valores observados.

\begin{tabular}{|c|c|c|c|}
\hline & Morphological Parameters & $\begin{array}{l}\mathbf{r}^{2}(\mathbf{y}=\mathbf{a}+\mathbf{b x}) \\
\text { Max. Vertical Pullout force }(\mathrm{kN}) \\
\text { Observed values }\end{array}$ & P-value \\
\hline \multirow{7}{*}{$\begin{array}{l}\text { Above } \\
\text { ground }\end{array}$} & Cross-sectional area of shoots $\left(\mathrm{mm}^{2}\right)$ & 0.55 & $<0.05$ \\
\hline & Diameter of cuttings $(\mathrm{cm})$ & 0.29 & $<0.05$ \\
\hline & Total length of shoots $(\mathrm{cm})$ & 0.41 & $<0.05$ \\
\hline & Total diameter of shoots $(\mathrm{mm})$ & 0.39 & $<0.05$ \\
\hline & Mean diameter of shoots (mm) & 0.47 & $<0.05$ \\
\hline & Mean cross-sectional area of shoots $\left(\mathrm{mm}^{2}\right)$ & 0.47 & $<0.05$ \\
\hline & Mean length of shoots $(\mathrm{cm})$ & 0.48 & $<0.05$ \\
\hline \multirow{5}{*}{$\begin{array}{l}\text { Below } \\
\text { ground }\end{array}$} & Total diameter of roots $(\mathrm{mm})$ & 0.53 & $<0.05$ \\
\hline & Total length of roots $(\mathrm{cm})$ & 0.48 & $<0.05$ \\
\hline & Total number of roots & 0.31 & $<0.05$ \\
\hline & Mean diameter of roots $(\mathrm{mm})$ & 0.35 & $<0.05$ \\
\hline & Cross-sectional area of roots $\left(\mathrm{mm}^{2}\right)$ & 0.44 & $<0.05$ \\
\hline
\end{tabular}

The tested $\mathrm{r}^{2}$ values for above ground morphological characteristics ranged from 0.29 to 0.55 . The crosssectional area of shoots was the plant characteristic which best explained the variations in maximal pullout force (i.e. it was the best in explaining the root anchorage of $P$. sellowianus).

On the other hand, the values tested for below ground morphological characteristics ranged from 0.31 to 0.53. The roots' total diameter was the best for explaining the variations in maximal pullout force or root anchorage from five below-ground parameters.

The $\mathrm{r}^{2}$ values show a positive correlation between the plants' morphological characteristics and its root system anchorage capacity. However, it is essential to note that $r^{2}$ was low, which may be related to the number of plants tested and the complex form in which plant roots physically interact with the soil.

\section{The best explanatory variable}

The cross-sectional area of shoots was the morphological characteristic which showed the best correlation with the vertical pullout resistance (root anchorage) among the 12 characteristics tested.

Vertical pullout resistance was influenced by different factors over the evaluation period. Figure 4 shows the maximal vertical pullout force as a function of the cross-sectional area of shoots, and it is possible to observe two tendencies. One of them takes place at 61-days old and another from 133 to 421-days old. The vertical pullout resistance at 61-days old when the cuttings had few and tiny roots was mainly due to adhesion between the soil and buried stem surface (bark). On the other hand, the cuttings' roots showed expressive diameters and lengths during the period between 133 and 421-days old, and vertical pullout resistance was mainly a root tensile strength response. These two tendencies have resulted in Equation $2(y=0.001 * x+0.0832)$, representing 61 days after planting the cuttings, and Equation $1(\mathrm{y}=0.0011 * \mathrm{x}+0.4557)$, which represents the growth between 133 and 421 days after plantation. Equations 1 and 2 are represented by high $\mathrm{r}^{2}$ values $(0.95$ and 0.98 , respectively), making it clear that there is a good relationship between the cuttings' above-ground traits and root-system resistance.

It is also important to note that Equation 1 (Fig. 2) was developed from the values observed between 133 and 421 days after planting and that their use must consider the confidence interval generated for the observed data. It is worth remembering that the linear equation's coefficient of determination obtained from the observed data is only $r^{2}=0.55$. Regarding Equation 2, it is worth noting that the cuttings had small roots and small quantities with a low support capacity, offering little resistance to the pullout because it is only the resistance of the friction generated between the cutting surface with the soil. Therefore, this equation only shows a growth trend in the anchoring capacity of the cuttings. 


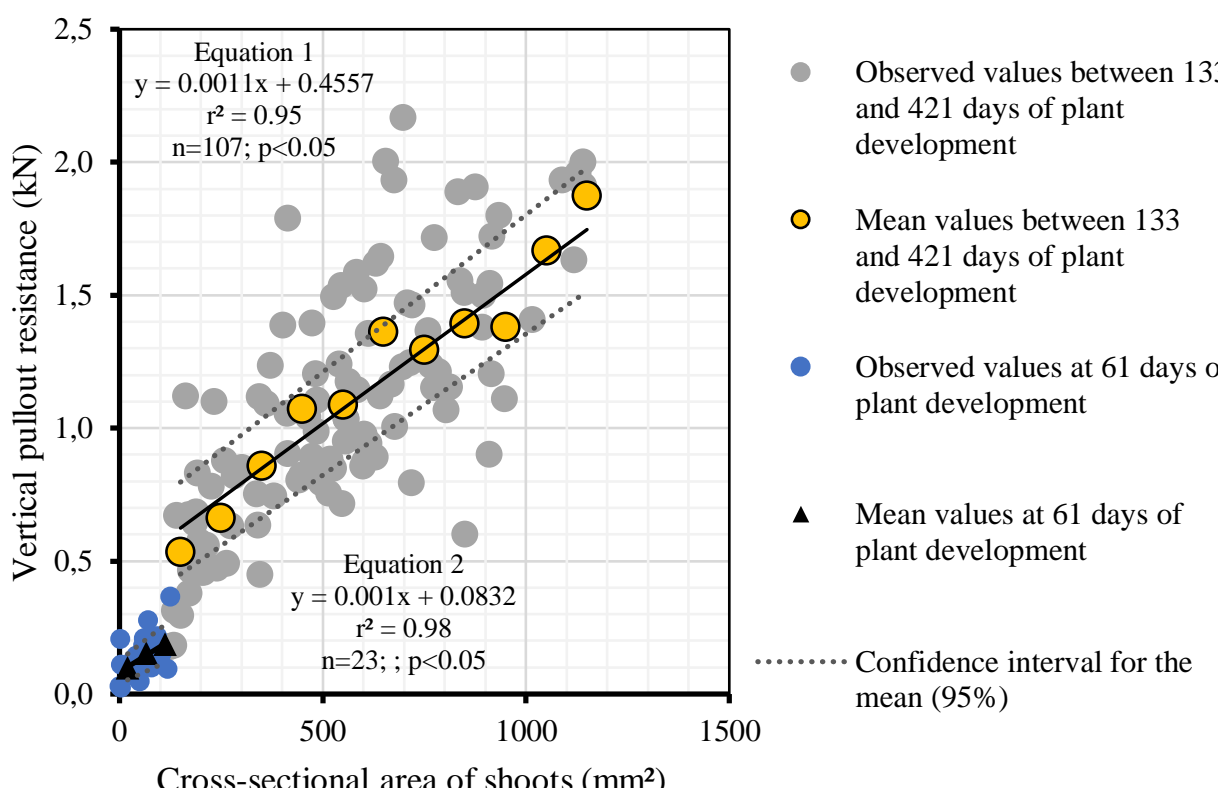

Figure 4. Relationship between cuttings' vertical pullout resistance and cross-sectional area of shoots of Phyllanthus sellowianus. The dashed lines represent the confidence interval for the mean (95\%).

Figura 4. Relação entre resistência máxima ao arranquio vertical e a soma da área transversal de brotos de Phyllanthus sellowianus. As linhas tracejadas representam o intervalo de confiança com $95 \%$ de confiabilidade.

\section{DISCUSSION}

The $P$. sellowianus cutting survival rate was relatively high $(>90 \%)$, and it was very similar to the result found by Sutili et al. (2018), whose values ranged from $97 \%$ to $100 \%$. According to the same authors, the high survival rate is due to the species' intrinsic characteristics, which can settle quickly in environments with adverse conditions (rapids, unstable margins, and poor soils). The species cuttings start to emit roots trying to establish themselves after about one week in contact with water or soil moisture. This characteristic is very relevant in soil bioengineering and degraded area recovery works, as it influences the cover and protection velocity of the soil (LIU et al., 2014), in addition to reducing replanting costs.

The changes in live cutting growth and root system resistance were influenced by the seasons. The general behavior of the tested variables was to increase until the late autumn, decrease in winter, and increase again in the spring. P. sellowianus cuttings showed the capacity to enhance its root system anchorage in more favorable growing seasons (spring, summer, and early autumn) when the average temperature is usually higher. It presented an average rate of $0.20 \mathrm{kN} / \mathrm{month}$, being followed by average increments in the total length of shoots and roots of 118.4 and $57.1 \mathrm{~cm} / \mathrm{month}$, respectively. Shoots and roots were damaged by frost during the winter, causing a significant reduction in growth and vertical pullout resistance. The root system resistance loss in this period was about $0.18 \mathrm{kN} / \mathrm{month}$, and losses in the total length of shoots and roots were about 100.0 and $30.0 \mathrm{~cm} / \mathrm{month}$, respectively.

The vertical pullout resistance values for $P$. sellowianus ranged from 0.028 to $2.17 \mathrm{kN} / \mathrm{cutting}$, which were very similar to those found by other authors such as Karrenberg et al. (2003), Burylo et al. (2009) and Liu et al. (2014), who worked with 3 (Populus nigra, Alnus incana and Salix elaeagnos), 12 (Pinus nigra, Quercus pubecens, Buxus sempervirens, Dorycnium pentaphyllum, Genista cinerea, Juniperus communis, Lavandula angustifolia, Ononis fruticosa, Ononis natrix, Staehelina dubia, Thymus serpyllum, and Anthyllis vulneraria) and 5 (Populus canadensis, Amorpha fruticosa, Salix alba var. Tristis, Salix purpurea and Salix matsudana cv. Umbraculifera) plant species, respectively.

The live cuttings' growth and resistance to vertical pullout analysis revealed that biometric variables generally explain about $50 \%$ of the variations presented in the resistance of the root system to pullout, showing similarity with that reported by Burylo et al. (2009) and Liu et al. (2014), who carried out their study on different soils and species. Both above- and below-ground characteristics showed several explanatory variables positively correlated with vertical pullout resistance (Table 1). This means that the selection of an appropriate morphological variable can enable obtaining a useful mathematical relationship to estimate the anchorage capacity of the plants, which is also an indicator of its contribution to soil reinforcement, as indicated by Wu et al. (2014) in pullout tests

FLORESTA, Curitiba, PR, v. 51, n. 2, p. 329-338, abril/jun 2021. 
of $1.0 \mathrm{~m}$ long cuttings of Salix exigua and Salix longifolia, which obtained values of $4.5 \mathrm{kN}$ for 13-month-old cuttings.

The cross-sectional area of shoots was the best to explain the parameter behavior related to root system anchorage capacity among all the morphological parameters tested, even surpassing the morphological variables of the roots, such as the total root diameter, total root length, total number of roots, mean root diameter and crosssectional area of roots. However, it is essential to highlight that the root system variables were measured after the pullout test, which may have influenced the relationships for the below-ground variables.

Regarding the relatively low $\mathrm{r}^{2}$, it is essential to note that even the capacity of an above-ground morphological variable to describe $50 \%$ of its root system's resistance variation can be very useful for an environment with several variation sources. For example, in a watercourse stabilization project, it will be possible to estimate how much force a species will be able to withstand before being removed by the water force from the place where it was planted using the diameter of the plant shoots and their growth expectation. This approach could be used in considering several species. Ultimately, this knowledge can contribute to planning and monitoring degraded area recovery projects.

\section{CONCLUSIONS}

- $\quad$ The biometric variables of $P$. sellowianus propagated from cuttings explained up to half of the variations in the anchorage capacity of the species;

- The anchorage capacity can be predicted by measuring one of its below or above ground morphological parameters;

- The morphological parameter which better described the variations in the root system resistance was the crosssectional area of shoots (CSAS);

- Despite having a significant relationship with root resistance, the root system is more challenging to measure than above ground morphological parameters.

\section{ACKNOWLEDGEMENTS}

The authors would like to thank the National Council for Scientific and Technological Development $(\mathrm{CNPq})$ for financial assistance in the form of a research grant and necessary supplies for the execution of this work.

\section{REFERENCES}

ALVARES, C. A.; STAPE, J. L.; SENTELHAS, P.C.; GONCALVES, J. L. M.; SPAROVEK, G. Köppen's climate classification map for Brazil. Meteorologische Zeitschrift, v. 22, n. 6, p. 711 - 728, 2013.

American Society for Testing and Materials. ASTM D3080/D3080M: standard method for direct shear test of soils under consolidated drained conditions. West Conshohocken; 2011.

BURYLO, M.; REY, F.; ROUMET, C.; BUISSON, E.; DUTOIT, T. Linking plant morphological traits to uprooting resistance in eroded marly lands (Southern Alps, France). Plant Soil, 324:31-42, 2009.

DOCKER, B. B.; HUBBLE, T. C. T. Quantifying root-reinforcement of river bank soils by four Australian tree species. Geomorphology, 100:401-418, 2008.

FORTIER, J.; TRUAX, B.; GAGNON, D.; LAMBERT, F. Plastic allometry in coarse root biomass of mature hybrid poplars plantations. Bioenergy Research, 8:1691-1704, 2015.

GENET, M.; STOKES, A.; SALIN, F.; MICKOVSKI, S. B.; FOURCAUD, T.; DUMAIL, J. F.; VAN BEEK, R. The influence of cellulose content on tensile strength in tree roots. Plant Soil, 278:1-9, 2005.

GRAY, D. H.; SOTIR, R. B. Biotechnical and soil bioengineering slope stabilization. John Wiley and Sons, Inc., New York, 1996, 378p.

JOHANSSON, T.; HJELM, B. Stump and roots biomass of poplar stands. Forests, 3:166-178, 2012.

KARRENBERG, S.; BLASER, S.; KOLLMANN, J.; SPECK, T.; EDWARDS, P.J. Root anchorage of saplings and cuttings of woody pioneer species in a riparian environment. Functional Ecology, v. 17, n. 2, p. 170 - 177 , 2003 .

LIN, D. G.; HUANG, B. S.; LIN, S.H. 3-D numerical investigations into the shear strength of the soil-root system of Makino bamboo and its effect on slope stability. Ecological engineering, 36:992-1006, 2010.

FLORESTA, Curitiba, PR, v. 51, n. 2, p. 329-338, abril/jun 2021 
LIU, Y.; RAUCH, H. P.; ZHANG, J.; YANG, X.; GAO, J. Development and soil reinforcement characteristics of five native species planted as cuttings in local area of Beijing. Ecological engineering, v. 71, p. 190 - 196, 2014.

LOADES, K. W.; BENGOUGH, A. G.; BRANSBY, M. F.; HALLETT, P.D. Planting density influence on fibrous root reinforcement of soils. Ecological engineering. 36:276-284, 2010.

MAFFRA, C. R. B.; MORAES, M. T.; SOUSA, R. S.; SUTILI, F. J.; PINHEIRO, R. J. B.; SOARES, J. M. D. Métodos de avaliação da influência e contribuição das plantas sobre a estabilidade de taludes. Scientia Agraria, V. 18, n. 4, p. 129 - 143, 2017.

MAFFRA, C. R. B.; SOUSA, R. S.; SUTILI, F. J.; PINHEIRO, R. J. B. The Effect of roots on the shear strength of texturally distinct soils. Floram, v. 26, p. 1-11, 2019.

MAFFRA, C. R. B. The use of soil bioengineering to overcome erosion problems in a pipeline river crossing in South America. Innovative Infrastructure Solutions, 24, 2020.

MICKOVSKI, S. B.; STOKES, A.; VAN BEEK, R.; GHESTEM, M.; FOURCAUD, T. Simulation of direct shear tests on rooted and non-rooted soil using finite element analysis. Ecological engineering, 37:1523-1532, 2011.

SCHIECHTL, H. Bioingegneria Forestale. basi - materiali da construzioni vivi - metodi. Itália: Edizione Castaldi-Feltre, 1 ed. 1973, 263p.

SCHIECHTL, H. M.; STERN, R. Ground bioengineering techniques for Slope protection and erosion control. Blackwell Science Publications, Oxford, 1996, 176p.

SCHWARZ, M.; LEHMANN, P.; OR, D. Quantifying lateral root reinforcement in steep slopes - from a bundle of roots to tree stands. Earth Surface Processes and Landforms, 35:354-367, 2010.

RITA, S. S.; MAFFRA, C. R. B.; DEWES, J. J.; PINHEIRO, R. J. B.; SUTILI, F. J. Engenharia Natural: O uso e avaliação das plantas de uma perspectiva de engenharia. Scientia Vitae, v. 9, n. 27, p. 1-13, 2020.

SOUSA, R. S.; MAFFRA, C. R. B.; SUTILI, F. J. Engenharia Natural para estabilização de travessia dutoviária Caso 1. Revista Ciência e Ambiente, 2017; 46-47: 131-152.

SUTILI, F. J.; DORNELES, R. S.; VARGAS, C. O.; KETTENHUBER, P. L. W. Avaliação da propagação vegetativa de espécies utilizadas na estabilização de obras de terra com técnicas de Engenharia Natural. Ciência Florestal, v. 28, n. 1, p. 1 - 12, 2018.

SUTILI, F. J.; DENARDI, L.; DURLO, M. A.; RAUCH, H. P.; WEISSTEINER, C. Flexural behavior of selected riparian plants under static load. Ecological engineering, 43:85-90, 2012.

WU, T. H. Root reinforcement of soil: review of analytical models, test results, and applications to design. Canadian Geotechnical Journal, 50:259-274, 2013.

WU, T. H.; KOKESH, C. M.; TRENNER, B. R.; FOX, P. J. Use of live poles for stabilization of a shallow slope failure. Journal of Geotechnical Geoenvironmental Engineering, 10.1061/(ASCE) GT.1943-5606.0001161, $05014001,1-13,2014$. 